\title{
Neonatal overfeeding induced glucocorticoid overexposure accelerates hepatic lipogenesis in male rats
}

\author{
Fan Yang ${ }^{1}$, Yanyan Dai ${ }^{1}$ Cuiting Min ${ }^{1}$ and Xiaonan $\mathrm{Li}^{1,2^{*}}$
}

\begin{abstract}
Background: Postnatal overfeeding activates tissue glucocorticoid (GC) activity by up-regulating $11 \beta$-hydroxysteroid dehydrogenase 1 (11ß-HSD1) and increasing sensitivity to high-fat (HF) diet-induced non-alcoholic fatty liver disease (NAFLD). The present study aimed to evaluate the effects of postnatal overfeeding on GC regulation and lipogenesis in the liver and to observe the impact of GC on hepatocyte lipid metabolism.

Methods: In vivo, Male Sprague-Dawley rat pup litters were adjusted to litter sizes of three (small litter, SL) or ten (normal litter, NL) on postnatal day 3 and then given standard chow from postnatal week 3 (W3) to W13. In vitro, HepG2 cells were stimulated by GC, mifepristone (Mi) or GC + Mi within 48 h, followed by sodium oleate (OA) intervention (or not) for $24 \mathrm{~h}$. Intracellular lipid droplets, triglyceride (TG) concentrations and gene expression related to lipid metabolism were measured in hepatic tissues or HepG2 cells.
\end{abstract}

Results: In vivo, weight gain in the body and liver and TG concentrations in the liver were significantly increased in the SL rats compared to the NL rats at W3 and W13 $(p<0.05)$; mRNA expression of hepatic 11ß-HSD1, acetyl-CoA carboxylase 1 (ACC), stearoyl-CoA desaturase-1 (SCD1), fatty acid synthase (FASN) and their nuclear transcription factor, sterol regulatory element binding protein-1C (SREBP-1c) $(p<0.05)$, was also increased. In vitro, intracellular lipid droplets and TG content in HepG2 cells increased under stimulation with GC or OA ( $p<0.05)$; the increase was more significant following treatment with GC and OA together $(p<0.05)$. The ACC, SCD1, FASN and SREBP-1c mRNA expression changes were highly similar to the changes in TG content in cells. All the changes induced by GC disappeared when the glucocorticoid receptor (GR) was blocked by Mi.

Conclusions: Postnatal overfeeding induced GC overexposure through $11 \beta$-HSD1 up-regulation in the liver. GC activated hepatic de novo lipogenesis (DNL) via GR and led to hepatic lipid accumulation, which increased the risk of NAFLD during adulthood.

Keywords: Glucocorticoid, NAFLD, Postnatal overfeeding, 11ß-HSD1, Glucocorticoid receptor

\section{Background}

Non-alcoholic fatty liver disease (NAFLD) and other components of metabolic syndrome (MS) have become increasingly comorbid with the increasing prevalence of obesity in both children and adults [1,2]. Unlike what happens in adults, the onset of paediatric NAFLD is asymptomatic until it progresses into hepatic fibrosis and cirrhosis $[3,4]$. In order to develop strategies to

\footnotetext{
* Correspondence: xiaonan6189@163.com

${ }^{1}$ Department of Child Health Care, Children's Hospital of Nanjing Medical University, 72 Guangzhou Road, Nanjing, China

${ }^{2}$ Institute of Paediatric Research, Nanjing Medical University, 140 Hanzhong Road, Nanjing, China
}

effectively prevent NAFLD and MS, it is important to better understand the mechanisms by which obesity increases susceptibility to NAFLD.

NAFLD is characterized by excessive triglyceride (TG) accumulation in the absence of significant alcohol consumption [1]. It is primarily caused by the imbalance of hepatic lipid homeostasis between the acquisition and removal of TG/fatty acid, which involves increased fatty acid/TG uptake, enhanced de novo lipogenesis (DNL), impaired fatty acid $\beta$-oxidation, and/or decreased lipid export in the liver. Several rate-limiting enzymes and transcription factors participate in hepatic lipid metabolism [5]. 
Hepatic lipoprotein lipase (LPL) and liver-type fatty acid-binding protein (L-FABP) are thought to play a central role in hepatic lipid uptake [6,7]. The activation of DNL to TG synthesis in the liver involves sterol regulatory element binding protein-1c (SREBP-1c) and lipogenic enzymes including fatty acid synthase (FASN), acetyl-CoA carboxylase 1 (ACC) and stearoylCoA desaturase-1 (SCD1) [8, 9]. In addition, fatty acid $\beta$ oxidation and lipid export in the liver involve peroxisome proliferator-activated receptor $\alpha$ (PPAR $\alpha)$, carnitine palmitoyltransferase 1 (CPT1) and microsomal triglyceride transfer protein (MTP) [10-15]. The activities of these enzyme systems are regulated by nutrition, the endocrine system and inflammation [16-18].

Glucocorticoid (GC), such as corticosterone and cortisol, affects fat accumulation and lipid and glucose metabolism [19, 20]. At the tissue level, GC exposure is determined not only by circulating levels, but also by the tissue-specific GC-activating enzyme $11 \beta$ hydroxysteroid dehydrogenase type $1(11 \beta-H S D 1)$ and the GC-inactivating enzymes $5 \alpha$-reductase type 1 $(5 \alpha R 1)$ and $5 \beta$-reductase $(5 \beta R)$ [21, 22]. Previous studies have shown that the overexpression of $11 \beta-H S D 1$ in tissue amplifies local GC action, which leads to increased accumulation of adipose tissue and metabolic disorders in both humans and rodents [23-26]. GC is involved in every stage of the pathogenesis of NAFLD [27]. In animal models, GC increases lipid biosynthesis within the liver that can lead to hepatic steatosis and increase circulating TG levels $[28,29]$.

The results of both experimental studies using animal models and clinical investigations have indicated that the early nutrition environment is associated with the development of obesity and MS in later life [30-33] and that GC is a possible mediator of the permanent programming of obesity, insulin resistance, and other metabolic dysregulations [34-36]. Previously, we reported that small litter (SL) rearing induced obesity in adult rats. The animals also had hyperinsulinemia, elevated circulating corticosterone levels, peripheral tissue-specific alterations in $11 \beta$-HSD1 expression and activity and $5 \alpha \mathrm{R} 1$ and $5 \beta R$ expression starting at puberty [37]. In addition, SL rats also displayed increased ACC activation in the livers and were more prone to develop NAFLD when challenged with high-fat (HF) diets [38]. Our hypothesis was that local GC activity plays the crucial role in the pathogenesis of hepatic steatosis by regulating lipid synthesis enzymes. Therefore, in this study we examined the expression patterns of $11 \beta-\mathrm{HSD} 1$ and $5 \alpha \mathrm{R} 1$ and $5 \beta R$ in the livers of SL rats, as well as those of lipid metabolism-related genes involved in hepatic DNL and fatty acid $\beta$-oxidation and lipid export. Moreover, we wanted to determine the action of GC on hepatic lipid metabolism. We first treated HepG2 cells with GC and then with $\mathrm{OA}$ in vitro to mimic hepatic $\mathrm{GC}$ overexposure in vivo.

\section{Methods \\ Animals and experimental design}

All animal studies were performed following the guidelines established by the University Committee on the Use and Care of Animals and were overseen by the Unit for Laboratory Animal Medicine at Nanjing Medical University (IACUC: 14030102). Male Sprague-Dawley rats were used. They were maintained under a controlled $12 / 12 \mathrm{~h}$ light/dark cycle in temperature $\left(22 \pm 2{ }^{\circ} \mathrm{C}\right)$ conditions with free access to food and water.

The experimental setup was similar to that described in Boullu-Ciocca [39]. In rats, the weaning period is postnatal week 3 , puberty is postnatal weeks $6-8$ and adulthood is week 9 and afterward [40]. In our previous studies, we showed that metabolism disorders in SL rats took place during postnatal weeks $13-16[38,41]$. Therefore, postnatal weeks 3 and 13 were selected as two experimental points of this study to examine the effects of early nutrition on adult health. On postnatal day 3 (P3), male pups were randomly redistributed to litter sizes of three (SLs) or ten (normal litters (NLs)) to induce early postnatal overfeeding or normal nutrition, respectively [42]. After weaning (P21, W3), the NL and SL rats were fed a standard diet (NL or SL group) until postnatal week 13 (W13). All rats were housed 3-4 per cage after weaning. Body weight and food intake were monitored weekly throughout life. The animals were killed at W3 and W13 after an overnight fast.

\section{Tissue collection}

The rats were anaesthetized with chloral hydrate (300 $\mathrm{mg} / \mathrm{kg}$ body weight, i.p.) after an overnight fast (12 h). Body weight was recorded. Each rat's liver was dissected and weighed, and the hepatosomatic index (HSI) was calculated as (liver weight/body weight) * $100 \%$ [43]. All tissue samples were snap-frozen in liquid nitrogen and stored at $-70{ }^{\circ} \mathrm{C}$ until gene expression analysis.

\section{Hepatic lipid assays}

Concentrations of TG in the liver and cells were determined using TG assay kits (E1013, Applygen, Beijing, China). The hepatic TG concentration was expressed relative to $1 \mathrm{~g}$ of liver protein. Hepatic protein concentrations were determined using a Pierce BCA protein assay kit with bovine serum albumin as the standard (Thermo Fisher Scientific, Rockford, IL, USA).

\section{Cell culture}

HepG2 cells, obtained from Keygen Biotech (Nanjing, China, ATCC HB-8065), were maintained in DMEM 
medium containing $10 \% \mathrm{FBS}$ and $1 \% \mathrm{P} / \mathrm{S}$ at $37{ }^{\circ} \mathrm{C}$ with $5 \% \mathrm{CO}_{2}$ (Thermo Scientific, $\mathrm{CO}_{2}$ incubator) in $75 \mathrm{~cm}^{2}$ flasks. Cells were plated in 6 -well plates at $2^{*} 10^{5}$ cells per well. The following day, confluent cells were starved for $6 \mathrm{~h}$ without FBS. Then, the cells were treated with $2.0 \mathrm{ml}$ of fresh supplemented culture medium containing dexamethasone (active GC, D4902, Sigma), mifepristone (glucocorticoid receptor (GR) antagonist, Mi, M8046, Sigma), both GC and $\mathrm{Mi}$, or vehicle (culture medium) for $48 \mathrm{~h}$, followed by exposure (or not) to sodium oleate (OA, O7501, Sigma), which is rich in fatty acids, for $24 \mathrm{~h}$. To evaluate the possible effects of GC on gene expression related to lipid metabolism, HepG2 cells were incubated with GC at different concentrations $(0,50,100,125,250$, 500 and $1000 \mathrm{nM} ; n=3$ for each concentration) and time (24, 36 and $48 \mathrm{~h}$ ) and to ascertain the maximal response. The effects of GC $(125 \mathrm{nM})$ combined with $\mathrm{Mi}$ at different concentrations $(0,0.1,1,5,10 \mu \mathrm{M})$ were then used $(n=3)$ to evaluate the individual and combined effects on the hepatic lipid homeostasis. The TG content in the cells was determined using commercial kits (E1013, Applygen, Beijing, China).

\section{Oil red $O$ staining}

At the end of incubation, the cultured cells were washed with PBS and fixed with $4 \%$ formaldehyde for $30 \mathrm{~min}$ at room temperature. Then, the cells were stained using Oil red $\mathrm{O}$ working solutions containing $6 \mathrm{ml}$ of Oil red $\mathrm{O}$ stock solution $(0.5 \mathrm{~g}$ in $100 \mathrm{ml}$ of isopropanol) and $4 \mathrm{ml}$ of $\mathrm{ddH}_{2} \mathrm{O}$ at $37^{\circ} \mathrm{C}$ for $30 \mathrm{~min}$. Staining was visualized by bright-field microscopy (BX51, OLYMPUS, Japan).

\section{Total RNA extraction and real-time PCR}

Total RNA was extracted from cells or liver tissues using Trizol (Invitrogen) according to the manufacturer's instructions and quantified spectrophotometrically at OD260. The integrity of the total RNA was assessed using agarose gel electrophoresis, and cDNA was synthesized using M-MLV reverse transcriptase (TAKARA) with $0.5 \mu \mathrm{g}$ of the RNA sample as recommended by the manufacturer. Genes of interest were analysed by real-time PCR using the SYBR GREEN ABI Prism 7500 sequence detector for the target genes, including SREBP-1c, ACC, SCD1, FASN, PPAR $\alpha$, LPL, L-FABP, CPT1 and MTP (Table 1). Expression of the target genes was normalized to the expression of glyceraldehyde-3phosphate dehydrogenase (GAPDH) (Table 1).

\section{Statistical methods}

Data are expressed as Means \pm SEM. Two-ways analysis of variance (ANOVA) tests were used to analyse body weight gain. Two-sided Student's $t$-test was used to analyse liver weight, hepatic lipid content, mRNA

Table 1 Primer sequences used for mRNA quantification by real-time PCR

\begin{tabular}{|c|c|c|}
\hline & Forward primer $5^{\prime}-3^{\prime}$ & Forward primer $5^{\prime}-3^{\prime}$ \\
\hline ACC rat & TGAAGGGCTACCTCTAATG & TCACAACCCAAGAACCAC \\
\hline SCD1 rat & СТСССТАССТССАССССТАТ & AACCAACCCTCTCGTTCAGT \\
\hline FASN rat & AAGAGTGGGAGAGCCTGTTC & AGTTCACCAAGCCTACCACA \\
\hline LPL rat & GCTTCCCCTTACTGGTTCC & AACTGGCAGGCAATGAGACT \\
\hline L-FABP rat & AAGGGAAGGACATCAAGGGG & CACTGCCTTGACCTTTTCCC \\
\hline CPT1 rat & ACGAAGAACATTGTGAGCGG & GAGGACCTTGACCATAGCCA \\
\hline MTP rat & AGCAACATGCCTACTTCTTACAC & TCACGGGTTCACTTTCACTG \\
\hline SREBP-1C rat & CGCTACCGTTCCTCTATCA & CTCCTCCACTGCCACAAG \\
\hline PPARa rat & AGCCATTCTGCGACATCA & CGTCTGACTCGGTCTTCTTG \\
\hline GAPDH rat & GGCTCTCTGCTCCTCCCTGTTCTA & CGTCCGATACGGCCAAATCCGT \\
\hline ACC hum & CACGCTCAAGTCACCAAGAA & GCAAATGGGAGGCAATAAGA \\
\hline SCD1 hum & GTTCGTTGCCACTTTCTTGC & TGGTAGTTGTGGAAGCCCTC \\
\hline FASN hum & CGGTGTTGAGTTCGTGGAG & CGGGGATAGAGGTGCTGAG \\
\hline LPL hum & TTCTCGTTGGCAGGGTTGAT & CTGACACTGTITCACGCCA \\
\hline L-FABP hum & TTCAAGTTCACCATCACCGC & TTATGTCGCCGTTGAGTTCG \\
\hline CPT1 hum & CAACTCACATTCAGGCAGCA & CGATGTGCTTGCTGTCTCTC \\
\hline MTP hum & CTGCTCAGACCTCAGACTCA & TCTCTGATGTCACTGCTACCA \\
\hline SREBP-1c hum & TTCCCAGCCCCTCAGATAC & GAGAAGCACCAAGGAGACGA \\
\hline PPARa hum & CCAGCATCCTCTCTCCAACT & AGGAAAACGAAGACCCAAGAT \\
\hline GAPDH hum & GTCGGAGTCAACGGATTTGG & CATGGGTGGAATCATATTGGA \\
\hline
\end{tabular}


Table 2 Food intake at W3, 4, 5, 6, 8, and 13 in NL and SL rats

\begin{tabular}{lll}
\hline & $\mathrm{NL}$ & $\mathrm{SL}$ \\
\hline Food intake (g/day) & & \\
3 wk & $9.1 \pm 0.2$ & $14.3 \pm 0.5^{* * *}$ \\
4 wk & $10.6 \pm 0.1$ & $18.9 \pm 0.3^{* * *}$ \\
5 wk & $14.1 \pm 0.7$ & $18.0 \pm 0.5^{* *}$ \\
6 wk & $22.1 \pm 0.2$ & $22.0 \pm 0.3$ \\
8 wk & $26.6 \pm 0.2$ & $26.4 \pm 0.1$ \\
13 wk & $27.5 \pm 0.6$ & $27.8 \pm 0.2$ \\
\hline
\end{tabular}

Data are expressed as the mean \pm SEM. Significant differences between groups of rats at corresponding time points were analyzed by two-sided Student's $t$-test ${ }^{* *} p<0.01,{ }^{* *} p<0.001$ vs. NL rats. $n=6$ in each NL and SL group

expression and the effects of different treatments in cell culture. Statistical significance was accepted at $p<0.05$.

\section{Results}

\section{Food intake and body weight}

The food intake of the SL rats increased significantly only at W3 to W5 compared to the NL rats $(p<0.01$, Table 2), and there were no significant differences between groups after that time $(p>0.05$, Table 2). Body weight increased with age in both groups $(p<0.001)$, and the SL rats gained more than the NL rats $(p<0.001)$; there was a significant interaction for weight gain in the SL rats with age $(p<0.001$, Fig. 1a).

\section{Liver weight and hepatic TG content}

The liver weight was higher in the SL rats compared to the NL rats at W3 and W13 ( $p<0.001$, Fig. 1b), but there was no significant difference in HSI between groups $(p>0.05$, Fig. 1c). Hepatic TG content was higher in the SL rats compared to the NL rats at W3 and W13 ( $p<0.001$, Fig. 1d).

\section{$11 \beta-H S D 1,5 a R 1$ and $5 \beta R$ mRNA expression in the liver at W3 and W13}

Hepatic $11 \beta$-HSD1 mRNA expression was higher in the SL rats compared to the NL rats at W3 $(p<0.001$, Fig. 2a) and W13 $(p<0.05$, Fig. 2b). Compared to the NL rats, hepatic $5 \alpha \mathrm{R} 1$ and $5 \beta \mathrm{R}$ mRNA expression was higher in the SL rats at W3 $(p<0.01$, Fig. 2a) but decreased significantly in the SL rats compared to the NL rats at W13 $(p<0.01$, Fig. 2b).

\section{mRNA expression of rate-limiting enzymes in hepatic} tissue at $\mathrm{W} 3$ and $\mathrm{W} 13$

Hepatic ACC, SCD1, FASN and SREBP-1c mRNA expression was significantly increased in the SL rats compared to the NL rats at W3 and W13 $(p<0.05$, Fig. 3$)$, whereas mRNA expression of LPL and L-FABP mRNA only increased in the SL rats at W3 $(p<0.05$, Fig. 3a), but not at W13 $(p>0.05$, Fig. $3 b)$. There were no significant differences in the expression of PPAR $\alpha$, CPT1 or MTP between the two groups at W3 or W13 ( $p>0.05$, Fig. 3).

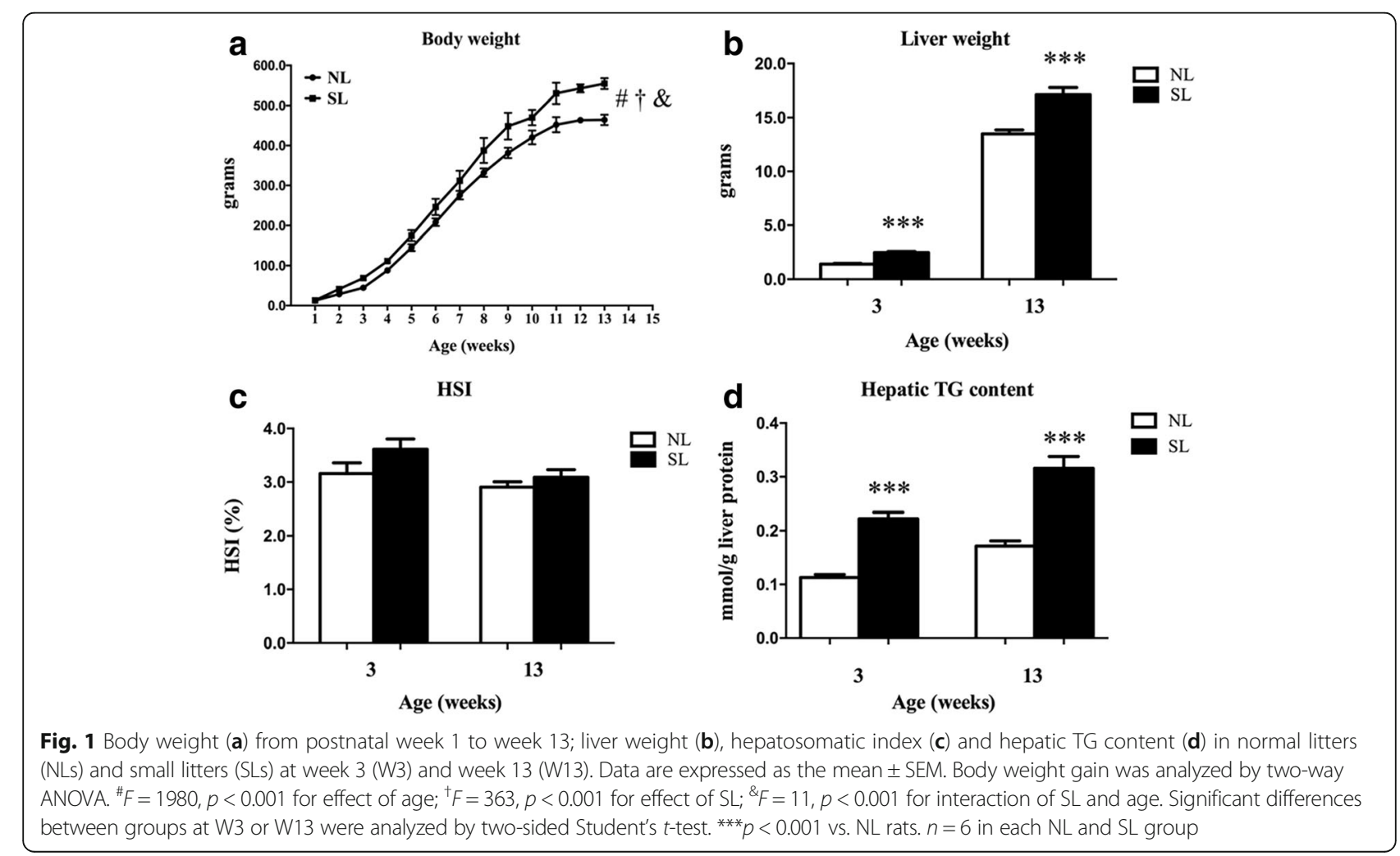



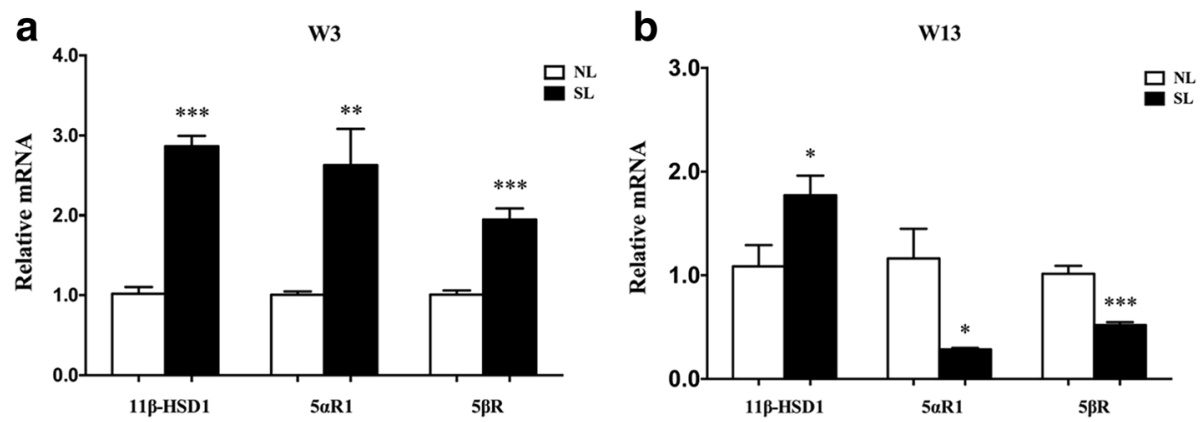

Fig. 2 mRNA expression of 11ß-HSD1, 5aR1 and 5BR at W3 (a) and W13 (b). Data are expressed as the mean \pm SEM. Significant differences between groups at W3 or W13 were analyzed by two-sided Student's t-test. ${ }^{*} p<0.05,{ }^{* *} p<0.01,{ }^{* * *} p<0.001$ vs. NL rats. $n=6$ in each NL and SL group

\section{Effects of GC or/and OA on lipid accumulation in HepG2 cells}

Oil red $\mathrm{O}$ staining showed that little lipid droplets existed in the normal HepG2 cells, but these intracellular lipid droplets were obviously increased in the cells after treatment with $\mathrm{GC}$ or OA; there was more significant lipid accumulation after treatment with $\mathrm{GC}+\mathrm{OA}$ (Fig. 4a). In addition, Mi treatment attenuated the increase of the lipid accumulation induced by GC or GC + OA (Fig. 4a). Like the lipid droplet accumulation, the TG content in the HepG2 cells increased after treatment with $\mathrm{GC}$ or $\mathrm{OA}$ or $\mathrm{GC}+\mathrm{OA}$ and decreased when Mi was added compared to the GC or $\mathrm{GC}+\mathrm{OA}$ treatment $(p<0.05$, Fig. $4 \mathrm{~b})$.

Gene expression in response to GC and OA in HepG2 cells To determine whether the regulation of hepatic lipid accumulation by GC was mediated by metabolism enzymes, we next examined ACC, SCD1, FASN and SREBP-1c mRNA expression in the HepG2 cells. As expected, the level of ACC mRNA was dependent on the dose and timing of the GC stimulation $(p<0.05$, Fig. $5 \mathrm{a}, \mathrm{b})$; the optimum concentration and timing were $125 \mathrm{nM}$ for $48 \mathrm{~h}$. SCD1, FASN and SREBP-1c
mRNA expression increased in GC stimulation $(p<0.05$, Figs. 6a, b, g), but CPT1 expression decreased $(p<0.05$, Fig. 6f), and all these alterations were more significant in the $\mathrm{GC}+\mathrm{OA}$ treatment $(p<0.05$, Fig. $7 \mathrm{~b}, \mathrm{c}, \mathrm{g}, \mathrm{h})$, as well as $\operatorname{ACC}(p<0.05$, Fig. 7a). Mi alone $(p>0.05$, Fig. 6$)$ and the $\mathrm{Mi}+\mathrm{OA}$ treatment $(p>0.05$, Fig. 7$)$ did not have any effect on the expression of these genes, but $\mathrm{Mi}$ attenuated $\mathrm{GC}$ or $\mathrm{GC}+\mathrm{OA}$ induced up-regulation of ACC, SCD1, FASN and SREBP-1c expression $(p<0.05$, Figs. $5 c, 6,7)$ and down-regulation of CPT1 expression $(p<0.05$, Figs. 6,7$)$.

\section{Discussion}

It has become increasingly recognized that the metabolic programming effects of nutritional modifications in early postnatal life are independently related to the development of obesity and MS in later life [31]. Overnutrition during lactation induces a persistent increase in body weight, hyperinsulinemia, hyperleptinemia and MS in adults, including NAFLD [30, 31]. Consistent with our previous reports, we confirmed that early neonatal overfeeding induced increased mRNA expression of $11 \beta-H S D 1$, decreased expression of $5 \alpha \mathrm{R} 1$ and $5 \beta \mathrm{R}$ and abnormal lipid metabolism in the livers of the SL rats compared to NL rats. The new finding of this study
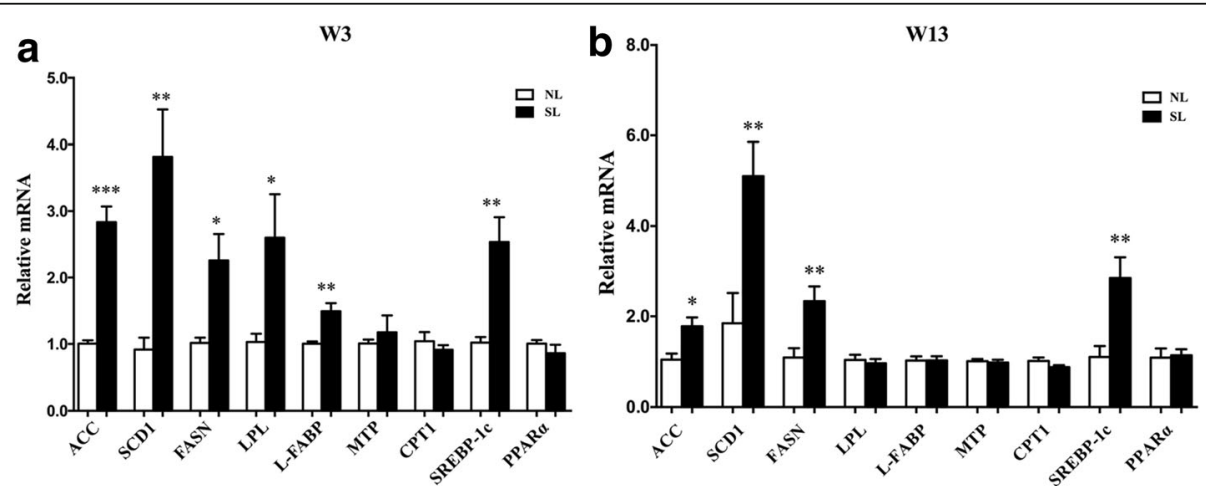

Fig. 3 mRNA expression of the genes involved in hepatic lipid metabolism at W3 (a) and W13 (b). Data are expressed as the mean \pm SEM. Significant differences between groups at W3 or W13 were analyzed by two-sided Student's $t$-test. ${ }^{*} p<0.05,{ }^{* *} p<0.01,{ }^{* * *} p<0.001$ vs. NL rats. $n=6$ in each NL and SL group 


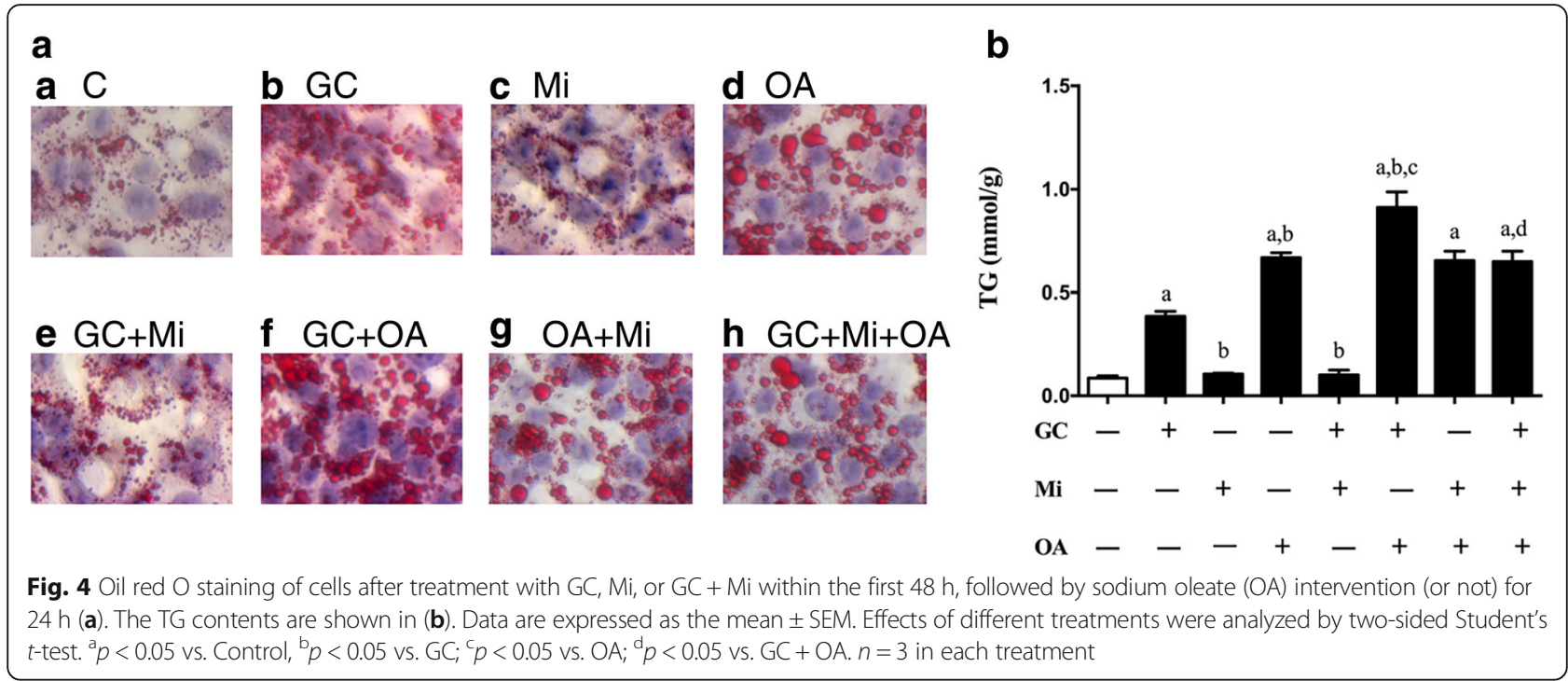

was that exposure to GC increased hepatocyte lipid accumulation by up-regulating the gene mRNA expression of hepatic DNL through GR. We suggest that early postnatal overfeeding induced by SL rearing leads to peripheral GC metabolism activity, which might contribute to the increase in hepatic lipid synthesis in adult rats.

Previous studies have shown the presence of higher $11 \beta$-HSD1 mRNA and/or activity in the adipose tissue of obese rodents $[24,25]$ or humans $[23,26] .11 \beta$-HSD1 is known to be positively associated with features of MS in adults [20]. Transgenic mice with adipose- or liverspecific $11 \beta$-HSD1 overexpression exhibit elevated intraadipose and portal corticosterone levels, abdominal obesity, dyslipidaemia, insulin resistance and hypertension $[44,45]$. In our studies, SL adult rats exhibited obesity and increased hepatic 11ß-HSD1 overexpression but decreased $5 \alpha \mathrm{R} 1$ and $5 \beta \mathrm{R}$ expression, indicating that there are more active GC in hepatic tissue. The high concentrations of GC in the liver could have important effects on lipid metabolism [28, 45, 46]. In the present study, small litters displayed significant increases in liver mass and TG contents compared to NL rats.

$\mathrm{GC}$ can lead to hepatic steatosis by decreasing lipid export and oxidation [47, 48], increasing cholesterol synthesis and fatty acid uptake $[49,50]$ or increasing lipid biosynthesis $[28,29]$. In addition to the changes of $11 \beta$-HSD1, $5 \alpha \mathrm{R} 1$ and $5 \beta \mathrm{R}$ in the liver, we also found that postnatal overfeeding induced a significant increase in DNL by SREBP-1c, ACC, SCD1 and FASN overexpression in the liver from weaning to adulthood, which might be an important mechanism underlying the development and progression of NAFLD in adulthood, that is, overexposure to GC through $11 \beta-H S D 1$ up-regulation in the liver.

In line with our hypothesis that overexposure to $\mathrm{GC}$ induces an increase in DNL in hepatocytes, we found that both lipid accumulation and TG content in HepG2 cells were significantly increased by GC treatment via DNL increase through SREBP-1c, ACC, SCD1 and FASN overexpression. Therefore, the augmented active

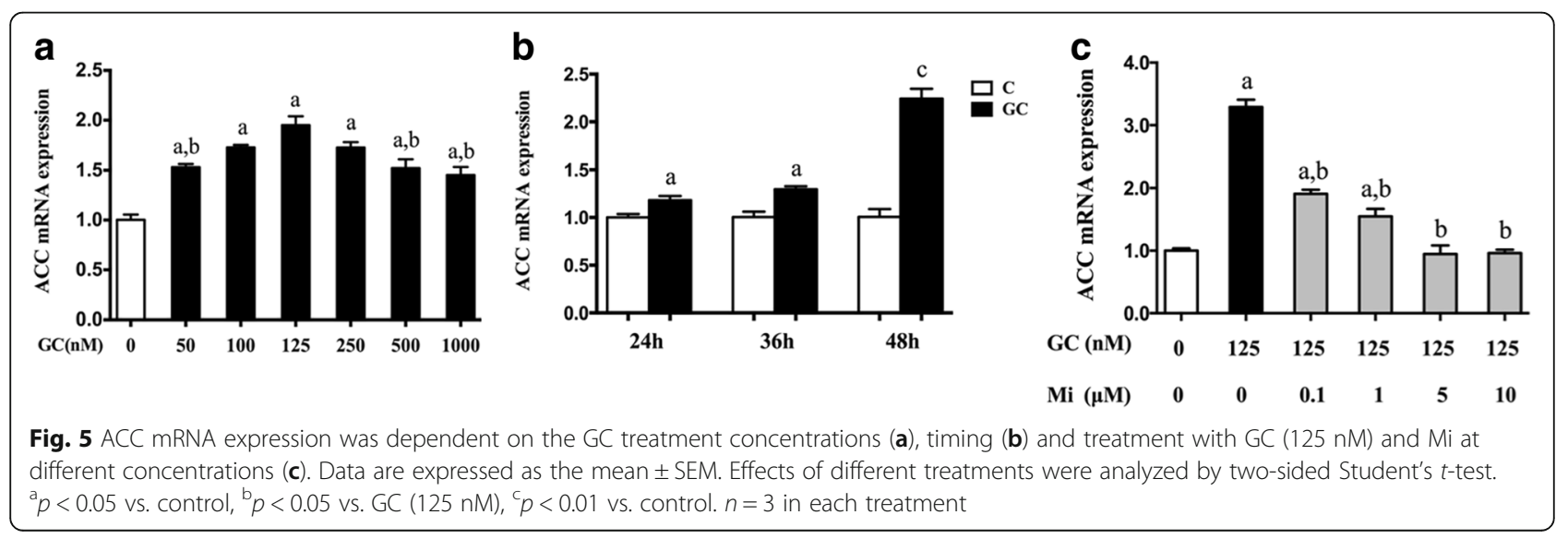



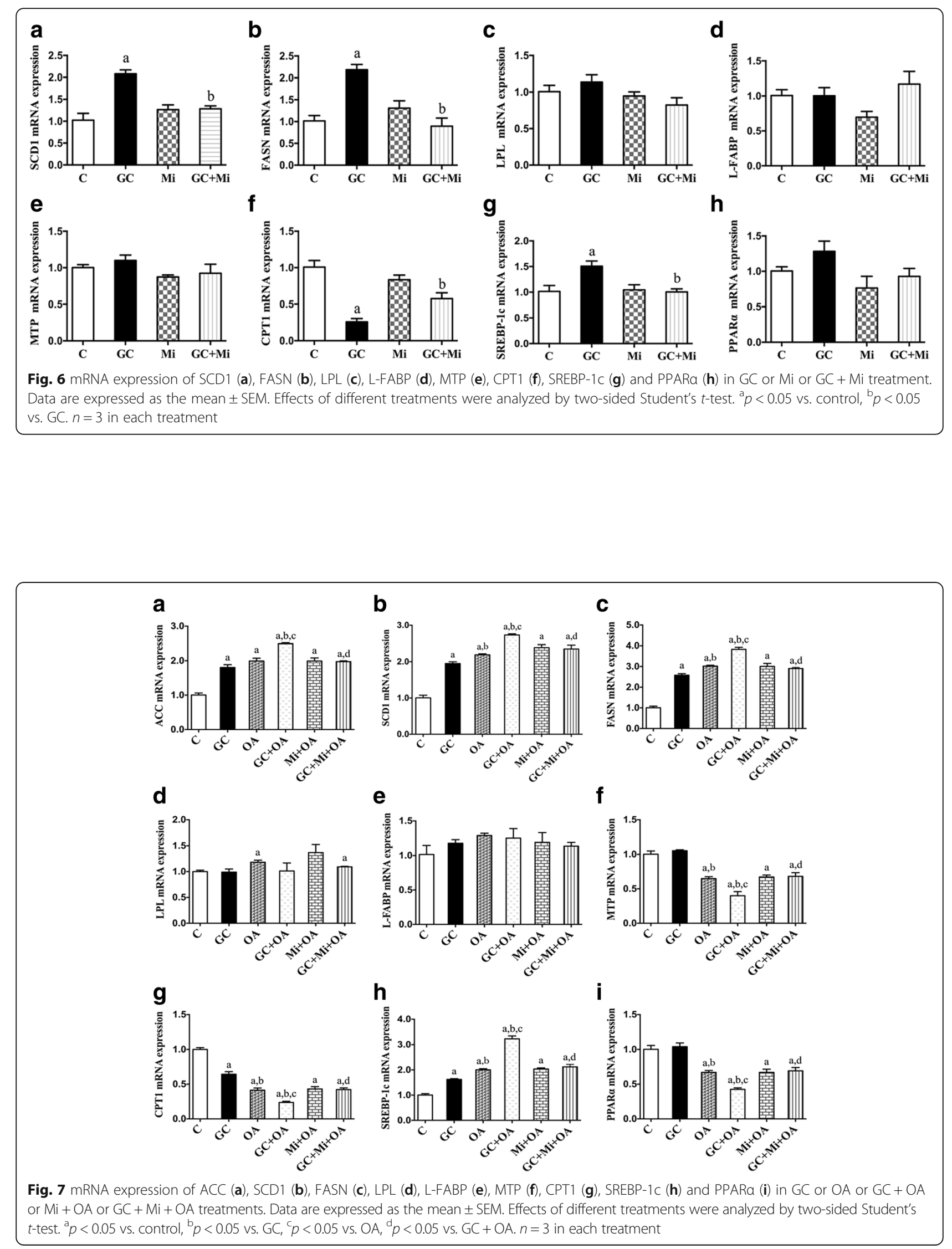
GC induced by the increase in $11 \beta-H S D 1$ might be an important factor responsible for the increased DNL in the livers of SL-reared rats. Because the effects of GC were mainly mediated via the GR, which is a member of the steroid hormone receptor superfamily [51, 52], we used Mi, the GR antagonist [53, 54], and confirmed that most of the hepatic lipid metabolism changes induced by GC were inhibited by Mi. Thus, we suggest that GC could increase lipid accumulation by increasing DNL through its receptor in the hepatocytes.

Although postnatal overfeeding can alter lipid metabolism in the liver, a high-fat diet is central to the onset of NAFLD [55, 56]. In our previous studies, we found that neonatal overfeeding in rats induced by SL rearing increased their vulnerability to a HF diet from postsuckling to adulthood and promoted early onset and exaggeration of HF diet-induced NAFLD [38]. Moreover, we found that SL and a high-fat diet exhibited a significant interaction with regard to $11 \beta-H S D 1$ expression, but hepatic $11 \beta$-HSD1 expression was not observed in NL-HF rats [57]. We suggest that the the increased activity of the GC induced by $11 \beta-H S D 1$ and a HF diet have a significant interaction on lipid metabolism in the liver. In the present study, we found that the $\mathrm{GC}+\mathrm{OA}$ treatment in vitro resulted in the most significant lipid accumulation and DNL increase in HepG2 cells compared to separate GC or OA treatments.

Previous studies have shown that during energy overconsumption, LPL and L-FABP expression increased in the liver $[58,59]$, but CPT1and MTP decreased $[60,61]$; all these alterations could contribute to the occurrence of NAFLD [27, 62]. In the present study, we found that CPT1 decreased after GC treatment in vitro, but it did not change at W13 in the SL rats. Notably, our previous observation indicated that CPT1 decreased at W16 in the SL rats [38], suggesting that long-term overexposure to GC also affected lipid oxidation in the hepatocytes. Furthermore, the transient elevation of LPL and L-FABP mRNA expression in the SL rats (at W3) might be due to the excessive food intake; it did not change after weaning in vivo or after $\mathrm{GC}$ overexposure in vitro. There was also no change in MTP or PPAR $\alpha$ caused by GC overexposure either in vivo or in vitro. Therefore, we suggest that GC overexposure in the SL rat model and HepG2 cells augmented the hepatic lipid accumulation mainly through DNL increase.

\section{Conclusions}

Postnatal overfeeding induced GC overexposure through $11 \beta$-HSD1 up-regulation in the liver, and the GC activated the hepatic DNL by GR. This resulted in hepatic lipid accumulation, leading to an increased risk of NAFLD during adulthood. More animal and clinical studies are needed to examine the prolonged effects of manipulating the availability of pre-receptor $\mathrm{GC}$ and the mechanisms of GR activation in the liver. Specifically, we suggest that targeting pre-receptor GC activation in the liver may provide a novel approach to the treatment of NAFLD, particularly in childhood.

\section{Abbreviations

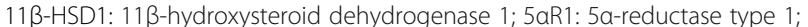

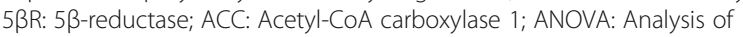 variance; CPT1: Carnitine palmitoyltransferase; DNL: De novo lipogenesis; FASN: Fatty acid synthase; GAPDH: Glyceraldehyde-3-phosphate dehydrogenase; GC: Glucocorticoid; GR: Glucocorticoid receptor; HF: High-fat: HSI: Hepatosomatic index; L-FABP: Liver fatty acid-binding protein; LPL: Lipoprotein lipase; Mi: Mifepristone; MS: Metabolic syndrome; MTP: Microsomal triglyceride transfer protein; NAFLD: Non-alcoholic fatty liver disease; NL: Normal litter; OA: Sodium oleate; P3: Postnatal day 3; PPARa: Peroxisome proliferator-activated receptor a; SCD1: Stearoyl-CoA desaturase-1; SL: Small litter; SREBP-1c: Sterol regulatory element binding protein-1c; TG: Triglyceride; W13: Postnatal week 13; W3: Postnatal week 3}

\section{Funding}

This work was financially supported by the National Natural Science Foundation of China $(81273064,81773421)$, the Innovation Team of Jiangsu Health (CXTDA2017035) and Jiangsu Province Social Development Research (BE2015607).

\section{Availability of data and materials}

Data are all contained within the article.

\section{Authors' contributions}

FY and $X \mathrm{~L}$ conceived and designed the experiments. FY and CM performed the animal experiment. FY and YD performed the cell experiment. YD and $\mathrm{CM}$ performed the analyses. FY and $\mathrm{XL}$ wrote the paper. YD and $\mathrm{CM}$ reviewed the manuscript. All authors approved the manuscript.

\section{Ethics approval and consent to participate}

All animal studies were performed following the guidelines established by the University Committee on the Use and Care of Animals and were overseen by the Unit for Laboratory Animal Medicine at Nanjing Medical University (IACUC: 14030102).

Competing interests

The authors declare that they have no competing interests.

\section{Publisher's Note}

Springer Nature remains neutral with regard to jurisdictional claims in published maps and institutional affiliations.

Received: 15 January 2018 Accepted: 18 April 2018

Published online: 02 May 2018

References

1. Rinella ME. Nonalcoholic fatty liver disease: a systematic review. JAMA. 2015; 313:2263-73.

2. Symonds ME, Sebert SP, Hyatt MA, Budge H. Nutritional programming of the metabolic syndrome. Nat Rev Endocrinol. 2009:5:604-10.

3. Feldstein AE, Charatcharoenwitthaya P, Treeprasertsuk S, Benson JT, Enders $\mathrm{FB}$, Angulo $\mathrm{P}$. The natural history of non-alcoholic fatty liver disease in children: a follow-up study for up to 20 years. Gut. 2009;58:1538-44.

4. Goyal NP, Schwimmer JB. The progression and natural history of pediatric nonalcoholic fatty liver disease. Clin Liver Dis. 2016;20:325-38.

5. Musso G, Gambino R, Cassader M. Recent insights into hepatic lipid metabolism in non-alcoholic fatty liver disease (NAFLD). Prog Lipid Res. 2009;48:1-26

6. Zhao Y, Peng L, Yang LC, Xu XD, Li WJ, Luo XM, Jin X. Wedelolactone regulates lipid metabolism and improves hepatic steatosis partly by AMPK activation and up-regulation of expression of PPARalpha/LPL and LDLR. PLoS One. 2015;10:e0132720. 
7. Hostetler HA, McIntosh AL, Atshaves BP, Storey SM, Payne HR, Kier AB, Schroeder F. L-FABP directly interacts with PPARalpha in cultured primary hepatocytes. J Lipid Res. 2009;50:1663-75.

8. Ding RB, Bao J, Deng CX. Emerging roles of SIRT1 in fatty liver diseases. Int J Biol Sci. 2017;13:852-67.

9. Cohen JC, Horton JD, Hobbs HH. Human fatty liver disease: old questions and new insights. Science. 2011;332:1519-23.

10. Carneiro L, Asrih M, Repond C, Sempoux C, Stehle JC, Leloup C, Jornayvaz FR, Pellerin L. AMPK activation caused by reduced liver lactate metabolism protects against hepatic steatosis in MCT1 haploinsufficient mice. Mol Metab. 2017:6:1625-33.

11. Xu J, Xiao G, Trujillo C, Chang V, Blanco L, Joseph SB, Bassilian S, Saad MF, Tontonoz P, Lee WN, Kurland IJ. Peroxisome proliferator-activated receptor alpha (PPARalpha) influences substrate utilization for hepatic glucose production. J Biol Chem. 2002;277:50237-44

12. Aoyama T, Peters JM, Iritani N, Nakajima T, Furihata K, Hashimoto T, Gonzalez FJ. Altered constitutive expression of fatty acid-metabolizing enzymes in mice lacking the peroxisome proliferator-activated receptor alpha (PPARalpha). J Biol Chem. 1998:273:5678-84.

13. Anstee $\mathrm{QM}$, Goldin RD. Mouse models in non-alcoholic fatty liver disease and steatohepatitis research. Int J Exp Pathol. 2006:87:1-16.

14. Wang L, Fast DG, Attie AD. The enzymatic and non-enzymatic roles of protein-disulfide isomerase in apolipoprotein B secretion. J Biol Chem. 1997; 272:27644-51.

15. Stefano JT, de Oliveira CP, Correa-Giannella ML, de Lima VM, de Sa SV, de Oliveira EP, de Mello ES, Giannella-Neto D, Alves VA, Carrilho FJ. Nonalcoholic steatohepatitis (NASH) in ob/ob mice treated with yo jyo hen shi ko (YHK): effects on peroxisome proliferator-activated receptors (PPARs) and microsomal triglyceride transfer protein (MTP). Dig Dis Sci. 2007;52:3448-54.

16. Purushotham A, Schug TT, Xu Q, Surapureddi S, Guo X, Li X. Hepatocytespecific deletion of SIRT1 alters fatty acid metabolism and results in hepatic steatosis and inflammation. Cell Metab. 2009:9:327-38.

17. Han H, Qiu F, Zhao H, Tang H, Li X, Shi D. Dietary flaxseed oil prevents western-type diet-induced nonalcoholic fatty liver disease in apolipoprotein-E knockout mice. Oxidative Med Cell Longev. 2017;2017:3256241.

18. Nasiri M, Nikolaou N, Parajes S, Krone NP, Valsamakis G, Mastorakos G, Hughes B, Taylor A, Bujalska IJ, Gathercole LL, Tomlinson JW. 5alphareductase type 2 regulates glucocorticoid action and metabolic phenotype in human hepatocytes. Endocrinology. 2015;156:2863-71.

19. Taves MD, Gomez-Sanchez CE, Soma KK. Extra-adrenal glucocorticoids and mineralocorticoids: evidence for local synthesis, regulation, and function. Am J Physiol Endocrinol Metab. 2011;301:E11-24.

20. Sapolsky RM, Romero LM, Munck AU. How do glucocorticoids influence stress responses? Integrating permissive, suppressive, stimulatory, and preparative actions. Endocr Rev. 2000;21:55-89.

21. Sheppard KE. Corticosteroid receptors, 11 beta-hydroxysteroid dehydrogenase, and the heart. Vitam Horm. 2003;66:77-112.

22. Chapman K, Holmes M, Seckl J. 11beta-hydroxysteroid dehydrogenases: intracellular gate-keepers of tissue glucocorticoid action. Physiol Rev. 2013, 93:1139-206.

23. Petrus P, Rosqvist F, Edholm D, Mejhert N, Arner P, Dahlman I, Ryden M Sundbom M, Riserus U. Saturated fatty acids in human visceral adipose tissue are associated with increased 11- beta-hydroxysteroid-dehydrogenase type 1 expression. Lipids Health Dis. 2015;14:42-6.

24. Zhang L, Zhou Y, Zhu AY, Li XQ, Mundt SS, Gao L, Lisnock J, Hernandez M, Alonso-Galicia M, Springer MS, O'Neill EA, Daugherty BL, Puig O. Metabolic syndrome in mice induced by expressing a transcriptional activator in adipose tissue. Transgenic Res. 2012;21:633-44.

25. Man TY, Michailidou Z, Gokcel A, Ramage L, Chapman KE, Kenyon CJ, Seckl JR, Morton NM. Dietary manipulation reveals an unexpected inverse relationship between fat mass and adipose 11 beta-hydroxysteroid dehydrogenase type 1. Am J Physiol Endocrinol Metab. 2011;300:E1076-84.

26. Anderson AJ, Andrew R, Homer NZ, Jones GC, Smith K, Livingstone DE, Walker BR, Stimson RH. Metformin increases cortisol regeneration by 11 betaHSD1 in obese men with and without type 2 diabetes mellitus. J Clin Endocrinol Metab. 2016;101:3787-93.

27. Woods CP, Hazlehurst JM, Tomlinson JW. Glucocorticoids and non-alcoholic fatty liver disease. J Steroid Biochem Mol Biol. 2015;154:94-103.

28. Staels B, van Tol A, Chan L, Verhoeven G, Auwerx J. Variable effects of different corticosteroids on plasma lipids, apolipoproteins, and hepatic apolipoprotein mRNA levels in rats. Arterioscler Thromb. 1991;11:760-9.
29. Glenny HP, Brindley DN. The effects of cortisol, corticotropin and thyroxine on the synthesis of glycerolipids and on the phosphatidate phosphohydrolase activity in rat liver. Biochem J. 1978;176:777-84.

30. Ojha S, Saroha V, Symonds ME, Budge H. Excess nutrient supply in early life and its later metabolic consequences. Clin Exp Pharmacol Physiol. 2013:40:817-23.

31. Patel MS, Srinivasan M. Metabolic programming in the immediate postnatal life. Ann Nutr Metab. 2011;58(Suppl 2):18-28.

32. Glavas MM, Kirigiti MA, Xiao XQ, Enriori PJ, Fisher SK, Evans AE, Grayson BE, Cowley MA, Smith MS, Grove KL. Early overnutrition results in early-onset arcuate leptin resistance and increased sensitivity to high-fat diet Endocrinology. 2010;151:1598-610.

33. Srinivasan M, Aalinkeel R, Song F, Mitrani P, Pandya JD, Strutt B, Hill DJ, Pate MS. Maternal hyperinsulinemia predisposes rat fetuses for hyperinsulinemia, and adult-onset obesity and maternal mild food restriction reverses this phenotype. Am J Physiol Endocrinol Metab. 2006;290:E129-34.

34. Khulan B, Drake AJ. Glucocorticoids as mediators of developmental programming effects. Best Pract Res Clin Endocrinol Metab. 2012;26:689-700.

35. Lindsay RS, Lindsay RM, Waddell BJ, Seckl JR. Prenatal glucocorticoid exposure leads to offspring hyperglycaemia in the rat: studies with the 11 beta-hydroxysteroid dehydrogenase inhibitor carbenoxolone. Diabetologia. 1996:39:1299-305

36. Lesage J, Del-Favero F, Leonhardt M, Louvart H, Maccari S, Vieau D, Darnaudery M. Prenatal stress induces intrauterine growth restriction and programmes glucose intolerance and feeding behaviour disturbances in the aged rat. J Endocrinol. 2004;181:291-6.

37. Hou M, Liu Y, Zhu L, Sun B, Guo M, Buren J, Li X. Neonatal overfeeding induced by small litter rearing causes altered glucocorticoid metabolism in rats. PLoS One. 2011;6:e25726.

38. Ji C, Dai Y, Jiang W, Liu J, Hou M, Wang J, Buren J, Li X. Postnatal overfeeding promotes early onset and exaggeration of high-fat dietinduced nonalcoholic fatty liver disease through disordered hepatic lipid metabolism in rats. J Nutr Biochem. 2014;25:1108-16.

39. Boullu-Ciocca S, Achard V, Tassistro V, Dutour A, Grino M. Postnatal programming of glucocorticoid metabolism in rats modulates high-fat dietinduced regulation of visceral adipose tissue glucocorticoid exposure and sensitivity and adiponectin and proinflammatory adipokines gene expression in adulthood. Diabetes. 2008;57:669-77.

40. Tirelli E, Laviola G, Adriani W. Ontogenesis of behavioral sensitization and conditioned place preference induced by psychostimulants in laboratory rodents. Neurosci Biobehav Rev. 2003;27:163-78.

41. Dai Y, Yang F, Zhou N, Sha L, Zhou S, Wang J, Li X. A post-weaning fish oil dietary intervention reverses adverse metabolic outcomes and 11 betahydroxysteroid dehydrogenase type 1 expression in postnatal overfed rats. Br J Nutr. 2016:116:1519-29.

42. Plagemann A, Harder T, Schellong K, Schulz S, Stupin JH. Early postnatal life as a critical time window for determination of long-term metabolic health. Best Pract Res Clin Endocrinol Metab. 2012;26:641-53.

43. Wootton RJ, Evans GW, Mills L. Annual cycle in female three-spined sticklebacks (Gasterosteus aculeatus L.) from an upland and lowland population. J Fish Biol. 2010;12:331-43.

44. Masuzaki H, Paterson J, Shinyama H, Morton NM, Mullins JJ, Seckl JR, Flier JS A transgenic model of visceral obesity and the metabolic syndrome. Science. 2001;294:2166-70.

45. Paterson JM, Morton NM, Fievet C, Kenyon CJ, Holmes MC, Staels B, Seckl $J R$, Mullins JJ. Metabolic syndrome without obesity: hepatic overexpression of 11 beta-hydroxysteroid dehydrogenase type 1 in transgenic mice. Proc Natl Acad Sci U S A. 2004;101:7088-93.

46. de Guia RM, Rose AJ, Sommerfeld A, Seibert O, Strzoda D, Zota A, Feuchter Y, Krones-Herzig A, Sijmonsma T, Kirilov M, Sticht C, Gretz N, Dallinga-Thie G, Diederichs S, Kloting N, Bluher M, Berriel Diaz M, Herzig S. microRNA-379 couples glucocorticoid hormones to dysfunctional lipid homeostasis. EMBO J. 2015;34:344-60.

47. Bocharov AV, Huang W, Vishniakova TG, Zaitseva EV, Frolova EG, Rampal P, Bertolotti R. Glucocorticoids upregulate high-affinity, high-density lipoprotein binding sites in rat hepatocytes. Metabolism. 1995:44:730-8.

48. Letteron P, Brahimi-Bourouina N, Robin MA, Moreau A, Feldmann G, Pessayre D. Glucocorticoids inhibit mitochondrial matrix acyl-CoA dehydrogenases and fatty acid beta-oxidation. Am J Phys. 1997;272:G1141-50.

49. Carr BR, Simpson ER. Cholesterol synthesis by human fetal hepatocytes: effects of hormones. J Clin Endocrinol Metab. 1984;58:1111-6. 
50. D'Souza AM, Beaudry JL, Szigiato AA, Trumble SJ, Snook LA, Bonen A, Giacca A, Riddell MC. Consumption of a high-fat diet rapidly exacerbates the development of fatty liver disease that occurs with chronically elevated glucocorticoids. Am J Physiol Gastrointest Liver Physiol. 2012;302:G850-63.

51. Hollenberg SM, Weinberger C, Ong ES, Cerelli G, Oro A, Lebo R, Thompson $E B$, Rosenfeld MG, Evans RM. Primary structure and expression of a functional human glucocorticoid receptor cDNA. Nature. 1985;318:635-41.

52. Uchoa ET, Aguilera G, Herman JP, Fiedler JL, Deak T, de Sousa MB. Novel aspects of glucocorticoid actions. J Neuroendocrinol. 2014;26:557-72.

53. Molitch ME. Diagnosis and treatment of pituitary adenomas: a review. JAMA. 2017;317:516-24.

54. Jiang Z, Qian L, Zou H, Jia Y, Ni Y, Yang X, Jiang Z, Zhao R. Porcine glucocorticoid receptor (NR3C1) gene: tissue-specificity of transcriptional strength and glucocorticoid responsiveness of alternative promoters. Steroid Biochem Mol Biol. 2014:141:87-93.

55. Morgan K, Uyuni A, Nandgiri G, Mao L, Castaneda L, Kathirvel E, French SW, Morgan TR. Altered expression of transcription factors and genes regulating lipogenesis in liver and adipose tissue of mice with high fat diet-induced obesity and nonalcoholic fatty liver disease. Eur I Gastroenterol Hepatol. 2008;20:843-54

56. Nakamura A, Terauchi Y. Lessons from mouse models of high-fat dietinduced NAFLD. Int J Mol Sci. 2013;14:21240-57.

57. Hou M, Ji C, Wang J, Liu Y, Sun B, Guo M, Buren J, Li X. The effects of dietary fatty acid composition in the post-sucking period on metabolic alterations in adulthood: can omega3 polyunsaturated fatty acids prevent adverse programming outcomes? J Endocrinol. 2012;215:119-27.

58. Ahn J, Lee H, Chung CH, Ha T. High fat diet induced downregulation of microRNA-467b increased lipoprotein lipase in hepatic steatosis. Biochem Biophys Res Commun. 2011;414:664-9.

59. Yang SY, Zhao NJ, Li XJ, Zhang HJ, Chen KJ, Li CD. Ping-tang recipe (平糖 方) improves insulin resistance and attenuates hepatic steatosis in high-fat diet-induced obese rats. Chin J Integr Med. 2012;18:262-8.

60. Nakade Y, Sakamoto K, Yamauchi T, Inoue T, Kobayashi Y, Yamamoto T, Ishii N, Ohashi T, Sumida Y, Ito K, Nakao H, Fukuzawa Y, Umezawa K, Yoneda M. Conophylline inhibits non-alcoholic steatohepatitis in mice. PLoS One. 2017; 12:e0178436.

61. Jia Y, Yee JK, Wang C, Nikolaenko L, Diaz-Arjonilla M, Cohen JN, French SW, Liu PY, Lue Y, Lee WP, Swerdloff RS. Testosterone protects high fat/low carbohydrate diet induced non-alcoholic fatty liver disease in castrated male rats mainly via modulating ER stress. Am J Physiol Endocrinol Metab. 2018;314:E366-76.

62. Higuchi N, Kato M, Tanaka M, Miyazaki M, Takao S, Kohjima M, Kotoh K, Enjoji M, Nakamuta M, Takayanagi R. Effects of insulin resistance and hepatic lipid accumulation on hepatic mRNA expression levels of apoB, MTP and LFABP in non-alcoholic fatty liver disease. Exp Ther Med. 2011;2:1077-81.

\section{Ready to submit your research? Choose BMC and benefit from:}

- fast, convenient online submission

- thorough peer review by experienced researchers in your field

- rapid publication on acceptance

- support for research data, including large and complex data types

- gold Open Access which fosters wider collaboration and increased citations

- maximum visibility for your research: over $100 \mathrm{M}$ website views per year

At BMC, research is always in progress.

Learn more biomedcentral.com/submissions 